\title{
What is the Jail Man Doing?
}

\author{
Simeneh Kiros Assefa * \\ (23 September, 2018)
}

\section{DOI: http://dx.doi.org/10.4314/mlr.v12i1.8}

I have no specific reason for writing this piece. However, I wanted to understand the things I usually see and make sense in light of what I think I know as 'law' and 'justice.' Justice Holmes, the legal realist, famously opined: it is the "prophecies of what the courts will do in fact, and nothing more pretentious, are what I mean by the law." I wish I could say the same; but this appears to be a far 'dignified' view of the law.

The moment you see a jail man with people in jail uniform, you certainly think he is enforcing 'the law' or a 'court order.' And if you are kind enough to imagine further, it is the 'majesty' of the law that comes to your mind. Of course! That is because you are trained to see things in that perspective. You know theories of crime; several doctrines and principles -some formal, some substantive and other procedural. You know the judicial process and how the rules 'work'. You also know the scaffolding evidentiary and procedural rules.

That is why you are representing your 'client' who is 'presumed to be innocent' until proven guilty to help him navigate through the 'complex' process of the administration of the 'criminal justice'. You are the professional 'conversant' in the language of the court. You meet him in court or in jail to help him with his case. He is in his jail uniform and you are in proper attire that is befitting the court because decorum is one ethical rule.

After the court day, if your client is denied bail, and the case is adjourned for next month or next year, you will be going home to play with your kids, to help them with their homework, or to a nearby café because you have an appointment with your friends and colleagues, or you might have other social function. We cannot say that for your client!

* LL.B (Addis Ababa University), LL.M (University of Pretoria), LL.M (Kyushu University), LL.M (University of San Francisco); Assistant Professor of Law at AAU Law School, Attorney-at-Law and member of California State Bar (inactive). Email: simeneh@simenehlaw.com 
After several appearances in court, assuming he is 'innocent', he would be acquitted. You think the judgment is fair while your client might think he is vindicated. You are trained in school while your client is trained in 'life' to think this way. You are desensitised against the fundamental ills of the social and political power structure which put your client at the bottom. He, on the other hand, is made to accept it.

\section{How is the law made?}

The law is made in Ethiopia not so different from how it is made in other jurisdictions. But it is different in certain important ways. Any state agency can initiate a bill in its area of competence. If it so desires to relieve itself from 'burdensome' administrative responsibilities, it may shift its obligations onto the citizen. If it so wishes further, it can attach severe criminal punishment to such obligations of the citizen.

The experts in the agency are 'the genius', conversant with the criminal law, and wise enough to know that the criminal law is there to enforce values anyway. So, they included severe criminal punishment in the bill for every little procedural infringement which the agency would have done otherwise to its best advantage.

The bill is then sent to the Council of Ministers, which includes probably only one person who 'understands' the law to explain to the Council. It is decided by 'consensus' that the bill be adopted and sent to the House of Peoples' Representatives. Most Members of the House, who make every primary law for the country, are not trained in law; they do not have legal advisors either. But the bill is read for Members of the House, in the first reading, who routinely decide that the matter be referred to a specific standing committee for a thorough review.

The Committee makes general discussion on the bill, but often not on the penal provision. In some instances, specific offices are invited for discussion on the matter, which is called a 'public hearing.' Often, questions only are raised at such hearing. But in rare instances, suggestions are also made regarding the bill, including the penal provisions. With little or no change to the draft bill, the Committee recommends the bill to the full House to adopt it into law. 
The discussion in the full House is limited to the 'reports and recommendations' of the Committee and the bill is ready for an up or down vote. It is not surprising that with strict party-discipline and single party controlled House, the bill would be adopted into law without the need to hand-twist any member.

\section{Other considerations}

Your client is charged for violating such law. Thus, the only (in)action of your client is trading without a commercial registration, or that is not renewed, or he failed to declare his income. Despite the lack of the 'moral blameworthiness' in the eye of the ordinary citizen, it may be the case that the facts or the law is so understood by those people working in chain the agency, police, prosecution office and the court, which might also include you, as part of the system.

On the other hand, the Government is campaigning that it would be 'tough' to reign on crime and 'enforce the law' to maximize state revenue for its 'welfare projects.' The judge hears the news of the Government's campaign. In writing the judgment, the judge evaluates your defence against the prosecution case; what is not expressed as part of the court's record (but is possibly in the mind of the judge) is the Government's campaign to 'enforce the law' and expand the state welfare projects.

Thus, if your client gets convicted, the jail man takes him back to jail because he is enforcing the law! I know you don't get shocked because several people perceive the events this way. Because of the constant reification, the value-laden and sophisticated words do not describe the simple facts that we are in 'misbelief'; and that we don't even believe we are in this state of affairs. What we think we know is not what is actually happening and we cannot describe it. But if we are asked to describe it, we certainly use the terms 'law' or 'justice' because we cannot use other terms which others do not understand. 